J. Krumm]. - Tübingen; Basel : A. Franke Verlag, 2010. - 370 S. 7. Handbuch Fremdsprachenunterricht / [K.-R. Bausch, H. Christ, H.-J. Krumm]. - Tübingen; Basel : A. Francke Verlag, 2007. - 656 s. 8. Hüllen W. Kleine Geschichte des Fremdsprachenlernens / W. Hüllen. Berlin : Erich Schmidt Verlag, 2005. - 184 s. 9. Krumm H.-J. «Bunt ist besser als nur deutsch» Mehrsprachigkeit und europäische Identität [Електронний ресурс]/ Н.-J. Krumm. - Режим доступу : http://fortbildung.phwien.ac.at/fortb_pe3/FileDownloads/ifu_02vortrag_ krumm.pdf. Заголовок з екрана. 10. Schröder K. Den Fremdsprachenunterricht der Schule verbessern. Eine Analyse aus deutscher Sicht [Електронний ресурс]/ K. Schröder. / [Consultation Conference Languages Learning Diversity (10. April 2003) / Workshop Improvising Languages Learning in Schools]. - Режим доступу : http://ec.europa.eu/ education/languages/pdf/doc342_de.pdf. Заголовок з екрана.

\title{
ПРОБЛЕМА ТРУДОВОГО ВИХОВАННЯ ТА ВСЕБІЧНО РОЗВИНЕНОЇ ОСОБИСТОСТІ НА СТОРІНКАХ РЕГІОНАЛЬНОГО ФАХОВОГО ПЕДАГОГІЧНОГО ВИДАННЯ
}

Євтухова Т. А. Проблема трудового виховання та всебічно розвиненої особистості на сторінках регіонального фахового педагогічного видання.

Стаття висвітлює питання трудового, екологічного, патріотичного виховання учнів навчальних закладів, порушені у працях сучасних дослідників. Проаналізовано праці науковців 3 проблем усебічного і гармонійного розвитку особистості, і зокрема трудового, патріотичного, екологічного виховання, на сторінках фахового періодичного видання «Гуманізація навчально-виховного процесу» з 2001 р. по 2006 р.

Ключові слова: збірник наукових праць, трудове, екологічне, патріотичне виховання, учні, трудова підготовка, трудове навчання, підростаюче покоління.

Евтухова Т. А. Проблема трудового воспитания и всестронне развитой личности на страницах регионального специализированного педагогического издания.

В статье рассматриваются вопросы трудового, екологического, патриотического воспитания учащихся, поднятые в работах современных исследователей. Проанализированы статьи ученых, в которых изучаются проблемы всестороннего гармоничного развития личности, и в частности трудового, патриотического, экологического воспитания, на страницах специализированного периодического издания «Гуманизация учебновоспитательного процесса» с 2001 по 2006 гг.

Ключевые слова: сборник научных трудов, трудовое, экологическое, патриотическое воспитание, учащиеся, трудовая підготовка, трудовое обучение, подрастающее поколение.

Yevtukhova T. A. The problem of labor education and well-rounded personality on the pages of the regional professional periodical pedagogical edition.

The article highlights the problems raised by researchers concerning labor, ecological, patriotic education of students. The scholars' works about the problems of well-rounded personality development are analyzed as well as labor, patriotic, ecological issues of education on the pages of the professional periodical edition «Humanization of the Educational process» from 2001 to 2006 are considered. 
Key words: periodical edition of scientific works, labor, ecological, patriotic education, students, labor training, labor learning, younger generation.

Сьогодення України вимагає реформ у всіх ланках освіти, забезпечення економічних і насамперед педагогічних умов для професійної самореалізації особистості. Дедалі все більше наголошується на якості освіти, приділяється увага універсальності підготовки випускника, його інформатизації, адаптованості до ринку праці.

На цьому тлі актуальним стає творче використання здобутків і традицій вітчизняної педагогіки. Вивчаючи історико-педагогічну спадщину, сучасні науковці прагнуть віднайти витоки провідних наукових ідей, які мають відіграти значну роль у процесі реформування освіти на шляху входження України до європейського освітнього простору.

Нашу увагу привернули періодичні наукові фахові видання, а саме збірник наукових праць Державного вищого навчального закладу «Донбаський державний педагогічний університет» «Гуманізація навчально-виховного процесу», який, на наш погляд, виконує роль оперативного поширювача і зберігача науково-теоретичної й оперативно-практичної інформації задля забезпечення поступального розвитку наукових досліджень і сприяння вдосконалення практичної діяльності в галузі педагогічної науки. Нас цікавлять сучасні дослідження таких нагальних освітніх проблем, як теорія і практика трудового й екологічного виховання, їхнє розв'язання в науковому доробку педагогів минулого.

Слід зазначити, що науковці неодноразово зверталися до проблеми друкованих засобів масової інформації аби проаналізувати їхню фахову різноманітність (Т. Завгородня, О. Коновець, М. Кухта, Г. Щука та ін.). Натомість не зазнали належного аналізу періодичні фахові видання щодо питань трудового й екологічного виховання.

Метою статmі є розгляд спеціалізованого періодичного видання «Гуманізація навчально-виховного процесу» із 2001 по 2006 рр. на предмет аналізу статей, у яких автори висвітлюють проблеми трудового й екологічного виховання учнівської молоді в різноманітних навчально-виховних закладах України.

Збірник наукових праць «Гуманізація навчально-виховного процесу» $\epsilon$ фаховим із педагогічних наук. Започатковано його було у 1996 р. кафедрою педагогіки Слов'янського державного педагогічного інституту (нині ДВНЗ «Донбаський державний педагогічний університет»). Ідея належить двом талановитим особам - фахівцю в галузі історії педагогіки, кандидату педагогічних наук, доценту Інзі Петрівні Внуковій i всебічно обізнаній особистості - кандидату педагогічних наук, професору Валерію Івановичу Сипченку. На сучасному етапі наукове видання нараховує 71 випуск i 15 спецвипусків. Збірник користується повагою і попитом серед освітян України, Росії, Азербайджану, Польщі, Болгарії. На його сторінках друкуються відомі й молоді науковці, здобувачі, студенти і магістранти, що роблять свої перші наукові кроки, педагоги-практики навчально-виховних закладів.

Питання, що розкривають автори у своїх працях, різнобічні, актуальні для сучасної освіти, такі, що потребують нагального розв'язання. Педагоги-науковці пропонують шляхи подолання труднощів і знаходять оптимальні, раціональні рішення проблем.

На нашу увагу заслуговують статті, у яких порушуються питання трудового й екологічного виховання учнів у навчальних закладах.

Так, звертаючись до спадщини педагогів минулого, Е. Панасенко у своїй статті описує теоретичні погляди Я. Чепіги щодо розбудови української національної школи. Педагогічна скарбниця Я. Чепіги нараховує 139 праць, у яких порушувалися нагальні питання освіти: 
побудова системи освіти, навчання рідною мовою, форми і методи навчання тощо. Я. Чепіга піддавав критиці стару систему освіти, говорячи про те, що національне виховання не повинно бути показовим, із присмаком шовінізму, а підростаюче покоління слід виховувати рідною мовою на засадах народних традицій і звичаїв, з урахуванням здобутків історії і культури.

Працюючи над створенням проекту національної школи в межах Російської імперії, Я. Чепіга висунув вимоги, завдання, постулати щодо побудови української школи. Як і майже 100 років тому прозорливі слова педагога залишаються значущими для сьогодення: «трухлявий організм сучасної схоластичної школи не можна оздоровити латками на ньому, тут потрібна радикальна операція і навіть руйнування всіх вигаданих підвалин і основ ...».

Авторка зазначає, що за укладеним проектом школа ділилася на два ступені: перший 2 роки навчання, другий - 4. Програма навчання дітей на першому ступені передбачала прогулянки на природу, заняття домашнім господарством: годування свійської худоби, посильну добровільну працю на земельних ділянках, у садах тощо. Протягом двох років учні не отримують теоретичних знань, а відомості з галузей знань надаються вчителями засобами народних казок, поезії, пісень. Велику увагу приділено ролі книжки та знанням із рідної мови [7, с. 11-15].

Скарбницю педагогічної мудрості презентує стаття М. Головкової «Розкриття сутності «принципу природності» на сторінках журналу «Учитель» у 70-х роках XIX ст.». Підвалини гуманістичного навчання й виховання закладено Я. Коменським, який обгрунтував загальнопедагогічний принцип виховання дитини згідно 3 iï природними здібностями, індивідуальністю. Цей принцип педагог уважав вищим принципом будь-якого виховання, що не суперечить природі дитини. Педагоги на сторінках журналу «Учитель» постійно висвітлювали ідеї навчання і виховання дітей в умовах «відкритого неба, лісів, лугів, садів». Отже, принцип індивідуального підходу, особистісно зорієнтованого навчання сягає далекого минулого [1, с. 21-25].

Формування рис патріотизму учнів початкової школи розкриває у своїх статтях О. Коркішко [3; 4]. Авторка зазначає, що еколого-патріотичні знання входять до системи загальнолюдської культури, а серед компонентів патріотизму належне місце посідають охорона і бережливе ставлення до природи рідного краю, навколишнього середовища. Тож формування патріотичних почуттів прямопропорційно залежить від залучення школярів до культурної спадщини українського народу.

Аналізуючи працю В. Сухомлинського «Природа, праця, світогляд» О. Коркішко погоджується з думкою великого педагога, що «природа - не тільки середовище навколо нас, а й всенародне добро і багатство, за яке кожний громадянин-патріот нашого суспільства відповідає - це червона нитка світоглядних переконань...». Далі дослідницею наводяться принципи екологізації процесу навчання та формування в дітей екологічної культури: любов до рідного краю, народу, родини; зростання екологічної свідомості; усвідомлення людиною себе як частки природи, відповідальне ставлення до природних багатств як національних цінностей; здобуття необхідних екологічних знань; залучення дітей до природоохоронної діяльності тощо.

Фахівець із патріотичного виховання звертає увагу на національні свята: Дні Конституції, Незалежності, Соборності України, Свято козацької слави, народно-релігійні свята веснянолітнього, осінньо-зимового циклів, сімейні свята, засновані на важливих подіях у родині і присвячені дням народження і ювілеям членів сім’ї, пам'яті померлих родичів, а також Дні родини, матері, батька. Також розкрито їхній виховний вплив на особистість молодшого школяра.

Педагогіка вищої та середної школи. - 2015. - Вип. 45 
О. Коркішко акцентує, що саме виховний процес у початковій школі слугує фундаментом для подальшого еколого-патріотичного виховання, що має позитивний вплив на розвиток особистості [3, с. 162-170].

Спираючись на концепцію патріотичного виховання, авторка акцентує на таких патріотичних цінностях, як: вияв любові до батьків, рідних, живої природи, шанування національної історії і традицій тощо. Зазначено, що виховання патріотизму молодших школярів відбувається під час вивчення «рідної мови та літератури, природознавства, народознавства, предметів художньо-естетичного циклу (музика, образотворче мистецтво), трудового навчання», у позанавчальний час.

Дослідниця у статті детально зупиняється на системі позаурочної роботи з патріотичного виховання, що досягається виконанням низки завдань: «формування самосвідомості, відповідальності..., суспільної ініціативності й активності, готовність працювати на благо свого народу та Батьківщини...; виховання дисциплінованості, працьовитості, турботливості, почуття дбайливого господаря своєї землі, піклування про іiі природу та довкілля». Визначено закономірності виховного процесу, вимоги до його організації, указано залежність результатів позаурочної роботи від взаємодії учасників навчально-виховного процесу, доброзичливого мікроклімату, взаємоповаги, вибір учнями форм проведення занять, постійне психологопедагогічне діагностування учнів, корекція взаємин учнів із педагогами позашкільних закладів тощо.

О. Коркішко означила принципи позакласної роботи: добровільності, особистого орієнтування, системності. Указано загальновідомі форми їі проведення: масові (вечори, конференції, зустрічі з ветеранами праці, конкурси, фестивалі, виставки, олімпіади тощо), групові (гуртки, екскурсії, походи, тематичні свята), індивідуальні (бесіди, доручення, колекціонування). Визначено напрями позаурочної виховної роботи: світоглядний, суспільно-корисний, трудовий, пізнавально-розвивальний, художньо-естетичний, військовоспортивний та методи до них. Зупинимось на трудовому і суспільно-корисному напрямі i конкретизуємо форми: трудовий - свято зустрічі птахів, першої борони, організація виставок, виготовлення гербаріїв, альбомів, написання газет тощо; суспільно-корисний догляд за могилами воїнів; участь в екологічних акціях, експедиціях, походах.

На наш погляд, О. Коркішко вдало представила систему патріотичного виховання в позаурочний час у вигляді схеми, що ілюструє зміст, мету, завдання, закономірності виховного процесу, принципи, напрями, форми і методи позаурочної роботи.

Отже, виховання гідного громадянина своєї держави залежить не тільки від об'єктивних і суб'єктивних чинників, а й від правильно продуманої системи виховної роботи [4, c. 99-103].

Науковцем М. Кареліним проаналізовано спадщину українських педагогів другої половини XIX століття О. Духновича, I. Жука, Т. Лубенця, М. Корфа, К. Ушинського, В. Фармаковського, І. Франка, М. Хитькова, П. Христіановича щодо трудового виховання учнів у загальноосвітніх закладах.

Так, автор зазначає, що відомий педагог О. Духнович, маючи на меті виховання високоморальної особистості, особливо наполягав на обов'язковості праці, адже основою моральної добропорядності вважав працездатність людини, що формується не тільки у процесі оволодіння знаннями у школі, а й у безпосередній трудовій діяльності. Він одним із перших сформулював умову наявності в кожній школі свого городу і саду, де б діти «у науці правильного землеробства вправлялися».

Справедливо зазначається, що О. Духнович став першим українським педагогом, у 
працях якого знаходимо теоретичне обгрунтування мети i завдань трудового навчання, визначення його як засобу всебічного виховання, також науковець окреслив зміст і методи трудового навчання за видами праці.

Автор зазначає, що «Праця в ії психічному і виховному значенні» (1860 р.) видатного науковця Костянтина Ушинського в науковому загалі визначається методологічною основою для розв'язання багатьох важливих проблем трудового виховання. Розглядаючи науковий доробок відомого педагога, М. Карелін зауважує, що корисним для здоров'я і таким, що стимулює всебічний розвиток дитини, К. Ушинський уважав чергування фізичної та розумової праці, він називав його одним із основних принципів правильної організації дитячої праці. Відтак відомий російський педагог наполягав на введенні уроків праці, створенні при міських школах майстерень, а при сільських - шкільних ділянок. Особливу увагу К. Ушинський приділяв ознайомленню дітей із сільськогосподарською працею, вбачаючи в ній неабияке виховне значення. На думку талановитого педагога, кожна сільська школа повинна була мати земельну ділянку для організованої педагогічної праці.

Розглядаючи праці М. Корфа - відомого педагога другої половини XIX ст., М. Карелін зазначає, що той продовжив ідеї К. Ушинського. Ремісниче навчання, на думку за М. Корфа, буде корисним додатком до класних занять із різних предметів і буде сприяти розумовому та фізичному розвитку дітей, навчає їх елементів різних ремесел, які можуть бути використаними в подальшому житті після навчання у школі.

Розглядаючи спадщину українського педагога Т. Лубенця, дослідник визначив його ідеї щодо організації трудового навчання. Так, видатний педагог уважав, що ручна праця повинна приносити реальну користь селянам, діти яких мали навчитися виготовляти граблі, вила, уміти полагодити сани, зробити вісь у воза або натягти на неї колесо.

У своїй статті М. Карелін проаналізував деякі думки й корисні пропозиції щодо організації трудового навчання школярів українського педагога Я. Чепіги. Відомий педагог уважав ручну працю у школі умовою гармонійного розвитку дитини, зазначаючи, що необхідно дбати, щоб ручна праця не обернулася на чисто механічну, де не стільки творчість і самодіяльність мають місце, скільки копіювання за шаблоном, оскільки, на думку педагога, у ручній праці мають культивуватися творчість, фантазія, розум і воля. Ручна праця, на думку Я. Чепіги, слугує засобом ознайомлення учнів із виробничим оточенням (вивчення сільськогосподарської техніки, екскурсії на промислове виробництво).

М. Карелін зосереджує увагу на педагогічних міркуваннях щодо трудового навчання відомого письменника I. Франка, який розглядав працю як важливу суспільну категорію, без якої неможливий прогрес суспільства. Цікавими є погляди I. Франка на організації таких шкіл, де б загальна освіта поєднувалася із трудовим навчанням і вихованням, а праця ставала засобом усебічного виховання дитини.

Український письменник постійно наполягав на створенні шкіл із органічним поєднанням грунтовного розумового виховання з трудовим.

Вимагали від школи навчання учнів різноманітних видів праці і зазначений М. Кареліним український педагог В. Фармаковський, а П. Христіанович акцентував увагу на наданні дитині знань, необхідних для життя, сприянні їі фізичному розвитку, розвитку поваги і прихильності дитини до «чорної» праці [2, с. 75-81].

Цікавим, на наш погляд, $\epsilon$ визначення трьох понять «трудове виховання», «трудова підготовка» i «трудове навчання» у статті Г. Лях. Авторка впевнена, що трудова підготовка $\mathrm{i}$ трудове навчання входять до змісту поняття «трудове виховання», тому що у процесі трудового виховання формується готовність до трудової діяльності, трудова підготовка забезпечує учнів 
системою теоретичних знань і практичних умінь. Трудове навчання спрямоване на вироблення у школярів трудових навичок і операцій.

Г. Лях зазначала, що в педагогіці існують близькі поняття «трудове виховання», «трудова підготовка», «трудове навчання», що розкривають сутність і завдання підготовки молодого покоління до життя і праці в нових умовах. Найширшим поняттям, на думку науковця, є трудове виховання, що містить і трудове навчання, i трудову підготовку. Трудове виховання - це сукупність дій вихователя і вихованця, яка забезпечує формування готовності до трудової діяльності. У свою чергу, готовність передбачає теоретичну, практичну i психологічну підготовку дітей і підлітків до праці. Отже, трудова підготовка є складником трудового виховання і передбачає: оволодіння системою знань про працю, загальноосвітніх $\mathrm{i}$ політехнічних знань про загальні основи виробничої діяльності людини, умінь і навичок, необхідних для трудової діяльності; формування мотивів, потреб, позитивного ставлення до праці, прагнення і бажання сумлінно і відповідально працювати, бережливого ставлення до результатів праці і поваги до людей праці. Складником трудового виховання $є$ також трудове навчання, яке означає процес навчання і вироблення у школярів умінь та навичок виконання тих чи тих трудових дій та операцій [5, с. 121-129].

Слід відзначити наукову статтю О. Олеярник «Професійна спрямованість старшокласників у педагогічній спадщині $\mathrm{B}$. Сухомлинського», опубліковану у проаналізованому нами збірнику.

Дослідник зазначає, що праці, як основному засобу виховання та формування особистості, видатний науковець ХХ століття В. Сухомлинський надавав особливого значення серед різноманітних сфер діяльності людини. Трудове виховання, на думку педагога-науковця, це, образно кажучи, гармонія трьох понять: треба, важливо і прекрасно. Воно досягає своєї мети, коли у процесі праці дитина пізнає світ, використовуючи нові знання. Удосконалюючи знаряддя праці, людина має змогу полегшити свої фізичні зусилля, а нові технології матимуть суттєвий вплив на якість і кількість виробленої продукції. В. Сухомлинський був упевнений в тому, що виховувати працелюбність і закріпити цю важливу рису можливо тільки в самому процесі праці [6, с. 156-161].

Отже, аналіз фахової періодики з висвітлення проблем трудового, екологічного, патріотичного виховання дає нам підстави вважати за доцільне використання і впровадження ідей видатних науковців у сучасну педагогічну практику для покращення стану виховання молоді і підготовки іiі до дорослої трудової діяльності, сумлінного ставлення до усвідомленого вибору професії.

Періодичні видання можуть слугувати не тільки джерелами наукової інформації, а й інструментом впливу на громадську свідомість, потужним поштовхом на особистість у формуванні національної гідності та для розв'язання актуальних освітянських проблем.

\section{Література}

1. Головкова М. М. Розкриття сутності «принципу природності» на сторінках журналу «Учитель» у 70-х роках XIX ст. / М. М. Головкова // Гуманізація навчальновиховного процесу: [зб. наук. праць] / [за заг. ред. проф. В. І. Сипченка]. - Вип. XV.Слов'янськ : СДПУ, 2001. - С. 21-25. 2. Карелін М. Українські педагоги другої половини XIX століття про трудове виховання учнів у загальноосвітніх закладах / М. Карелін // Гуманізація навчально-виховного процесу: [зб. наук. праць] / [за заг. ред. проф. В. I. Сипченка]. - Вип. XXVIII. - Слов'янськ : СДПУ, 2005. - С. 75-81. 3. Коркішко О. Підготовка майбутнього вчителя до позаурочної роботи 3 патріотичного виховання / О. Коркішко // Гуманізація навчально-виховного процесу : [зб. наук. праць] / [за заг. ред. проф. 
В. І. Сипченка]. - Вип. ХХ. - Слов'янськ : СДПУ, 2003. - С. 99-103. 4. Коркішко О. Г. Еколого-патріотичне виховання молодших школярів засобами народного календаря / О. Г. Коркішко // Гуманізація навчально-виховного процесу : [зб. наук. праць] / [за заг. ред. проф. В. І. Сипченка]. - Вип. XV. - Слов'янськ : СДПІ, 2001. - С. 162-170. 5. Лях Г. Проблеми трудової підготовки підростаючого покоління у зарубіжній педагогіці / Г. Лях // Гуманізація навчально-виховного процесу: [зб. наук. праць] / [за заг. ред. проф. В. І. Сипченка]. Вип. XXXI. - Слов'янськ: СДПУ, 2006. - С. 121-129. 6. Олеярник О. Професійна спрямованість старшокласників у педагогічній спадщині В. О. Сухомлинського / О. Олеярник // Гуманізація навчально-виховного процесу : [зб. наук. праць] / [за заг. ред. проф. В. І. Сипченка]. - Вип. ХXXII. - Слов'янськ : СДПУ, 2006. - С. 156-161. 7. Панасенко Е. А. Концепція створення української національної школи у педагогічній спадщині Я. Ф. Чепіги / Е. А. Панасенко // Гуманізація навчально-виховного процесу: [зб. наук. праць] / [за заг. ред. проф. В. І. Сипченка]. - Вип. XV. - Слов'янськ : СДПУ, 2001.C. $11-15$.

УДК 378.091(477)"19”

Марина Сщенко

\section{ОРГАНІЗАЦІЯ ТА РОЗВИТОК ДОВИШІВСЬКОЇ ОСВІТИ У ВИЩИХ НАВЧАЛЬНИХ ЗАКЛАДАХ УКРАЇНИ (ДРУГА ПОЛОВИНА ХХ СТОЛІТТЯ)}

Єщенко М. Г. Організація та розвиток довишівської освіти у вищих навчальних закладах України (друга половина ХХ століття).

У статті досліджено організацію та розвиток довишівської освіти в Україні у другій половині XX століття. Узагальнено і проаналізовано ключові твердження законодавчої бази 1948-1990-х років. Визначено мету та завдання довузівської освіти досліджуваного періоду. Доведено, що довишівська підготовка виступала необхідним елементом системи «загальноосвітня школа - вищий навчальний заклад». Обгрунтовано правила прийому, навчання та зарахування до ВНЗ випускників підготовчих курсів і відділень. Установлено, що навчання на підготовчих відділеннях здійснювали висококваліфіковані викладачі, які використовували різноманітні технології навчання. Виявлено позитивний вплив навчання на підготовчих курсах і відділеннях для подальшого вступу до ВНЗ. Охарактеризовано різні види профорієнтаційної діяльності, що сприяли популяризації вищої освіти в Україні.

Ключові слова: безперервна освіта, вища освіта, ВН3, довишівська освіта, підготовчі відділення, підготовчі курси, підготовчі факультети, профорієнтація, слухачі, студенти, школа.

Ещенко М. Г. Организация и развитие довузовского образования в высших учебных заведениях Украины (вторая половина XX века).

В статье исследовано организацию и развитие довузовского образования в Украине во второй половине XX века. Обобщены и проанализированы ключевые положения законодательной базы 1948-1990-х годов. Доказано, что довузовская подготовка выступала необходимым элементом системы «общеобразовательная школа - высшее учебное заведение». Обоснованы правила приёма, обучения и зачисления в вуз выпускников подготовительных курсов и отделений. Обнаружено положительное влияние обучения на подготовительных курсах и отделениях для дальнейшего поступления в вузы.

Ключевые слова: непрерывное образование, высшее образование, вуз, довузовское

Педагогіка вищої та середної школи. - 2015. - Вип. 45 